Chirurgia (2019) 114: 475-486

No. 4, July - August

Copyright@ Celsius

http://dx.doi.org/10.21614/chirurgia.114.4.475

\title{
Could Early Postoperative Complications be Considered as Risk Factor for Recurrence after Pillonidal Sinus Surgery?
}

\author{
Suleyman Demiryas ${ }^{1}$, Turgut Donmez ${ }^{2}$ \\ 'Department of General Surgery, Cerrahpasa Faculty of Medicine, Istanbul University-Cerrahpasa, Istanbul, Turkey \\ ${ }^{2}$ Department of General Surgery, Bakirkoy Doctor Sadi Konuk Training and Research Hospital, Istanbul, Turkey
}

Corresponding author: Suleyman Demiryas, MD Department of General Surgery Cerrahpasa Faculty of Medicine Istanbul University-Cerrahpasa Istanbul, Turkey E-mail: suleyman.demiryas@istanbul.edu.tr

\section{Abbreviations:}

$\mathrm{PD}$ - pilonidal disease

KP - Karydakis procedure

MLF - modified Limberg flap

HAAD - history of acute abscess drainage

WI - wound infection

DO - duration of operation

RDA - return to daily activity

EC - early complications

OMPCT - off-midline primary closure

techniques

$\mathrm{OH}$ - open healing

IRB - Institutional Review Board

BMI - body-mass index

TSR - timing of suture removal

FP - follow-up period

TDR - timing of drain removal

HP - hospitalization period

$\mathrm{RDA}$ - return to daily activity

PC - primary closure

LF - Limberg Flap

LC - late complications

Received: 10.07.2019

Accepted: 11.08.2019

\section{Rezumat}

Pot complicațiile postoperatorii timpurii să fie considerate factori de risc pentru recurență, ca urmare a intervenției chirurgicale pentru boala pilonidală sacrococcigiană?

Introducere: $\mathrm{Nu}$ s-a ajuns la nici un consens în ceea ce priveşte tehnicile de tratament ale bolii pilonidale sacrococcigiene (PD). Tehnicile chirurgicale preferate sunt procedurile Karydakis (KP) şi clapa Limberg modificată (MLF). Din cauza perioadei lungi de urmărire a pacienților şi a timpului îndelungat până la reluarea activităților zilnice, complicațiile postoperatorii crează un disconfort puternic. Prin prezentul studiu ne-am propus să determinăm factorii de risc pentru posibile complicații şi mai ales recurența la pacienții care sunt supuşi tratamentului chirurgical pentru PD.

Metode: Acesta este un studiu retrospectiv de şapte ani, care a fost realizat în perioda ianuarie 2011 - ianuarie 2018, în cadrul căruia au fost evaluați opt sute patruzeci şi unu de pacienți. Aceeaşi tehnică - aceeaşi abordare chirurgicală a fost folosită pentru toți pacienții implicați. Toate cazurile au fost împărțite în două grupuri: $\mathrm{KP}(\mathrm{n}=417)$ şi MLF $(\mathrm{n}=424)$.

Rezultate: Nu s-a găsit nicio diferență semnificativă între grupurile KP şi MLF în ceea ce priveşte vârsta, sexul, IMC, fumatul, istoricul drenării acute de abces (HAAD), momentul eliminării suturii, perioada de urmărire, seromul, hematomul, dehiscența, infecția rănilor (WI), durere şi recurență. În acest studiu, perioada de urmărire a pacientilor a fost de 48,6 $\pm 21,4$ luni în grupul KP şi 48,2 $\pm 21,7$ luni în grupul MLF (medie \pm SD). S-a constatat că scorul American Society of Anesthesiologists (ASA) a fost mai mare în grupul KP. În timp ce durata medie a operației (DO) a fost mai scurtă în grupul KP, perioada de îndepărtare a scurgerii, perioada de 
spitalizare şi revenirea la activitatea zilnică (RDA) au fost mai lungi. A existat un efect de îmbunătățire stabilit al IMC, HAAD, DO şi RDA asupra dezvoltării complicațiilor timpurii (CE) în ambele grupuri şi a scorurilor ASA asupra dezvoltării CE în grupul KP. Rata de recurență a fost determinată a fi de $6 \%$ în CP şi de 4,72\% în grupurile MLF. În ambele grupuri s-a constatat că dehiscența sau WI sunt factori de risc pentru recurență.

Concluzie: Deşi DO-ul său este scurt, tehnica KP prezintă unele dezavantaje, cum ar fi HP prelungit şi RDA întârziată. O corelație pozitivă semnificativă a fost găsită între diverşi factori, cum ar fi IMC mai mare, prezența HAAD, DO prelungită, ADR prelungită şi dezvoltarea EC în ambele grupuri. Am ajuns la concluzia că dehiscența şi WI de la CE pot fi evaluați ca factori de risc independenți pentru reapariție. De asemenea, am concluzionat că reapariția poate fi prevenită dacă îngrijirea plăgii este realizată cu atenție la pacienții la care a apărut dehiscență sau infecție a plăgii.

Cuvinte cheie: boala pilonidală, procedura Karydakis, clapa Limberg modificată, dehiscența, infecția rănilor, recurența

\begin{abstract}
Background: There is no widespread consensus in treatment techniques of sacrococcygeal pilonidal disease (PD). Among surgical techniques, especially Karydakis procedure (KP) or modified Limberg flap (MLF), are frequently preferred. Causing prolonged follow-up and return to daily activity, postoperative complications are very annoying. We aimed to determine risk factors for possible complications and especially recurrence in the patients undergoing surgical treatment for PD.

Methods: This is a seven-year retrospective study, which was conducted between January 2011 and January 2018. Eight hundred forty-one patients were evaluated in this work. We performed the same technique-the same surgeon approach in our surgical treatment. All cases were divided into two groups as $\mathrm{KP}(\mathrm{n}=417)$ and $\mathrm{MLF}(\mathrm{n}=424)$.

Results: It was found no significant difference between the KP and MLF groups in terms of age, gender, BMI, smoking, history of acute abscess drainage (HAAD), the timing of suture removal, the follow-up period, seroma, hematoma, dehiscence, wound infection (WI), pain and recurrence. In this study, the follow-up period of patients was $48.6 \pm 21.4$ months in KP group and $48.2 \pm 21.7$ months in MLF group (Mean $\pm \mathrm{SD}$ ). American Society of Anesthesiologists (ASA) score were found to be higher in the KP group. While mean duration of operation (DO) was shorter in the KP group, the timing of drain removal, hospitalisation period and return to daily activity (RDA) were longer. There was an established enhancing effect of BMI, HAAD, DO, and RDA on the early complications (EC) development in both of the groups, and of ASA scores on the EC development in the KP group. The rate of recurrence ratio was determined to be $6 \%$ in the KP and $4.72 \%$ in the MLF groups. In both of the groups, dehiscence or WI was found to be risk factors for recurrence.

Conclusion: Although its DO is short, KP technique bear some of the disadvantages such as prolonged HP and delayed RDA. A significant positive correlation was found between various factors such as higher BMI, presence of HAAD, prolonged DO, prolonged RDA and the development of EC in both groups. We concluded that dehiscence and WI from EC may be evaluated as independent risk factors for recurrence. We also concluded that recurrence may be prevented if wound care is carried out carefully in the patients who developed dehiscence or wound infection.
\end{abstract}

Key words: pilonidal disease, Karydakis procedure, Limberg Flap, dehiscence, wound infection, recurrence 


\section{Introduction}

Pilonidal disease (PD) is a common chronic disease caused by the chronic irritation and secondary infection of hair follicles often located in the gluteal cleft (1-3). It was initially described in 1833 by Herbert Mayo (1). Incidence of PD is between 26-700 / 100,000. It primarily affects young adults and is three times more common in men than in women $(1,3-8)$.

$\mathrm{PD}$ is the most often seen health problem worldwide. The main predisposing factors include family history, obesity (such as deep natal cleft), long-lasting sitting, chronic trauma and irritation such as driving, occupation, poor local hygiene, dark skin color and hairiness $(3,7,9)$. PD is a significant cause of morbidity and loss of work productivity $(4,10,11)$. Currently, the most widely accepted view is that a disease acquired nonliving hair creates a foreign body reaction in subcutaneous tissue and causes the formation of an abscess and sinus $(1,5,9,12-14)$.

In the acute abscess of $\mathrm{PD}$, treatment should be done with un-roofing and drainage. Delayed definitive surgery is often preferred after abscess drainage $(8,15)$. There has been no consensus on the treatment of chronic PD. There is consensus that chosen of ideal surgical technique should eliminate disease (cure); minimizing the length of hospital stay, return to normal daily activity, duration of wound care, postoperative pain, skin scarring, recurrence rate and postoperative complications (7,14-16). Frequently preferred PD treatment methods are off-midline primary closure techniques (OMPCT). Excision with open healing $(\mathrm{OH})(1)$, excision with marsupialization(1), excision with primary closure $(4,16)$, excision with flap closure such as Karydakis, Limberg, V-Y Techniques $(5,12,17-19)$ may be selected as surgical procedures in the chronic case. It is undeniable fact that wound care and personal hygiene are critically important factors for PD patients during the postoperative period.

We aimed to determine risk factors for possible complications and especially recurrence in the patients undergoing surgical treatment for PD. Thus, we evaluated the results obtained from the PD patients treated with modified KP or Modified Limberg Transposition Flap (MLF) techniques $(5,17)$. The effects of both preoperative and operative factors on morbidity were also evaluated.

\section{Methods}

This study includes nine hundred consecutive patients. The patients, who underwent flap technique procedure for the treatment of chronic PD, belong to either KP $(n=450)$ or MLF $(n=450)$ groups. Procedures were done at three medical centers: Department of General Surgery, Cerrahpasa Faculty of Medicine, Istanbul University-Cerrahpasa, Istanbul, Turkey, Department of General Surgery, Lutfiye Nuri Burat Government Hospital, Istanbul, Turkey, and Department of General Surgery, Esenyurt Necmi Kadıoglu Government Hospital, Istanbul, Turkey between January 2011 and January 2018 and all patients gave their consent before the operations. This retrospective study was carried out according to the Declaration of Helsinki with the approval of the Cerrahpasa Institutional Review Board (IRB) (IRB) date/ number: March 07, 2018 / 89608). The selection of the type of surgical procedure was realized with the surgeons' choice and the patients' consent. Patients who did not give one of these surgical techniques were operated using different techniques, but were excluded from the study. Uniform flap techniques were performed by following surgeons T.D., MD (for MLF), S.D., MD (for KP) and Z.C., MD (for KP). We followed the same technique-the same surgeon approach in our surgical treatment. Patients with acute abscess, psychiatric disorders and coagulopathy were excluded from the study. Patient interviews were conducted by phone. Fifty-nine patients total from the KP $(n=33)$ and MLF $(n=26)$ groups were not followed up and excluded from the study. The patient files were evaluated and then demographic variables, BMI, American Society of Anesthesiologists physical status classification (ASA) scores, anesthesia application methods, 
surgical complications, and factors affecting morbidity [smoking, history of acute abscess drainage (HAAD), and duration of operation (DO), etc.] were recorded. Surgical complications were divided into two groups as early (seroma, hematoma, dehiscence, wound infection (WI), acute pain) and late (chronic pain and recurrence).

Bowel preparation was not administered to patients. The gluteal area surrounding the intergluteal sulcus of each patient was first shaved right before the operation. Following the regional or general anesthesia, each patient was brought to the Jack-knife position and both hips of patients were then retracted laterally by using medical adhesive tapes. The surgical area and surrounding skin were cleaned with $10 \%$ povidone iodine prior to operation. The anus region was closed by a drape and excluded from the surgical area. With the help of the "Mosquito" clamp, hairs were removed from the sinuses. One mL-diluted methylene blue was injected slowly into the sinus tracts to define the course and extension limits of the sinus. This preparation was applied to all patients with PD.

In the KP group, patients underwent Karydakis flap described by Bessa (Fig. 1), after an excision by using an asymmetric elliptical incision (17,18). An asymmetric elliptical incision was performed as follows: the upper and lower ends of the ellipse were planned to be approximately $2 \mathrm{~cm}$ lateral to the middle line. Skin incisions were done by a scalpel. Then an excision of disease affected tissue area and preparation of flap were performed. Diathermy was used only in hemostasis. All sinuses and secondary openings were removed to the sacral fascia. The medial side of the wound was prepared with only superficial damage to the underlying gluteus muscle fascia at a distance of at least $5 \mathrm{~cm}$ to form a flap that fits the entire length of the wound followed by carefully draining under the flap and fixing the flap to the sacral fascia with 0-0 polyglactin sutures. Finally, the flap was fixed with polyglactin $2 / 0$ sutures placed $1 \mathrm{~cm}$ apart into the subcutaneous tissue. The skin was sutured with a vertical mattress technique using polypropylene $3 / 0$ stitches.

In the MLF group, after excision by rhomboid-shaped incision, patients received fasciocutaneous flap (Fig. 2) repair according to LF technique modified by Mentes et al (5). Excision was carried out based on the basic principles of the KP technique. First flap's cephalic apex was prepared in the midline and caudal apex was done in the $2 \mathrm{~cm}$ to inferior midline. Then, a fasciocutaneous rhomboid transposition flap prepared from the corresponding gluteal region was placed in the asymmetric rhomboid defect. The lower end of the flap was completely freed and the rhomboid defect was transposed medially to fill it without

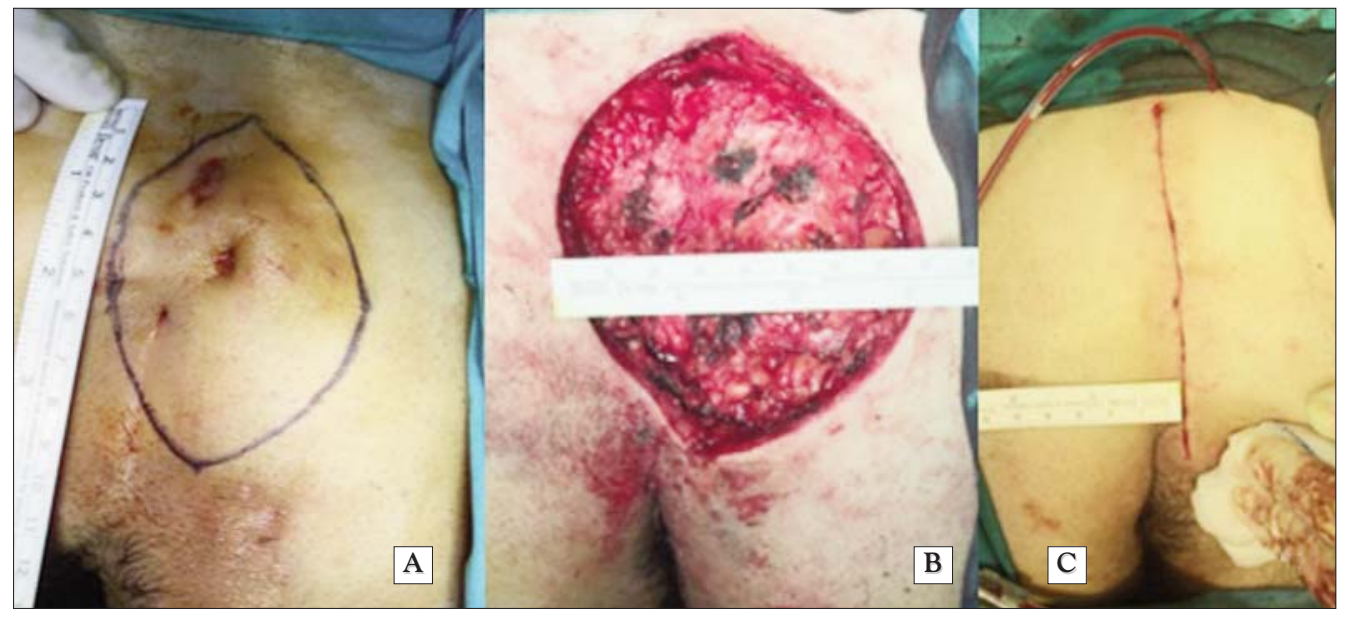

Figure 1. Karydakis procedure. A. Preparation, B. After excision, C. Subcutaneous tissue was closed 


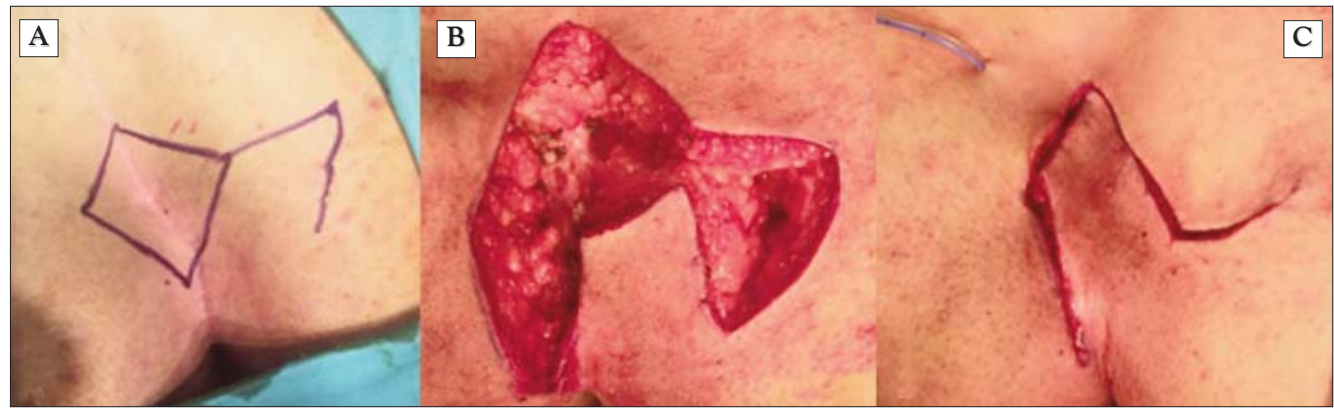

Figure 2. Modified Limberg transposition flap. A. Preparation, B. After excision, C. The subcutaneous tissue was closed

tension followed with caution to the drain under flap. The fixing of flap was performed to the sacral fascia with 0-0 polyglactin sutures where $2 / 0$ sutures were placed $1 \mathrm{~cm}$ apart into the subcutaneous tissue area. Skin was sutured by the technique used in KP.

A 12 French suction drain was placed under the flap in both groups. When the volume of the drainage reached 10 milliliters / 24 hours or less in the following two days, the drain was removed. $1500 \mathrm{mg}$ Cefuroxime axetil and $500 \mathrm{mg}$ of metronidazole were administered intravenously (IV) from the route of the peripheral vein for the purpose of antibiotic prophylaxis just before the operation and after 12 hour from operation. Two doses of dexketoprofen - trometamol IV were also administered for postoperative analgesia in the first 48 hours. After 24th the postoperative hour, parenteral antibiotics were switched to oral tablets $(500 \mathrm{mg}$ cefuroxime axetil tablets and $500 \mathrm{mg}$ metronidazole tablets)in order to prevent wound infection. Oral antibiotic administration were continued to patients until the end of the first postoperative week. In analgesia, $25 \mathrm{mg}$ dexketoprofen tablets were prescribed. Patients were advised to pay close attention to their personal hygiene and avoid excessive flexion of the hip joint for at least 15 days. The patients were called for check-up on the 7th day after discharge and on the days when the sutures were scheduled for removal. They were also recommended to epilate the hairs of the gluteal sulcus and surrounding area.

A physician who did not operate on these patients communicated with them by phone, and asked the following questions:

1. When did you start your daily activities, such as sitting down or watching television, without feeling any discomfort in the surgical area after discharge?

2. Did you have any problem with PD operation after the discharge? For example, PD recurrence, ongoing pain, etc.

In both patients groups, we made phone questionnaire for the postoperative 12th month of the last surgical operation who were included in our study.

Patients, who developed infections in the surgical area,were prescribed with an oral dose of $1 \mathrm{~g}$ amoxicillin-clavulanate and $500 \mathrm{mg}$ metronidazole. In case of purulent infection, stitches were removed from the suture line allowing drainage followed by antibiotherapy. Wound care was performed with a regular wet dressing. Since patients with seroma did not show any sign of infection, they were not prescribed antibiotic. Only needle aspiration was applied to the patients. Patients who developed hematoma were prescribed antibiotics and monitored daily. Wet dressing was applied to patients with dehiscence followed by antibiotherapy procedure.

\section{Statistical Analysis}

Categorical variables were expressed in percentages, and continuous variables were depicted as mean \pm standard deviation. In categorical variables, Chi-square test was used 
for comparison of two groups. KolmogorovSmirnov test was used to test normality and determine the distribution of continuous variables. Afterwards, for continuous variables, independent t-test was used for comparison of two groups. The $p$ value of less than 0.05 was considered significant. Number Cruncher Statistical System-2007, Statistical Software Package Program (NCSS 2007, Utah, USA) was used for statistical analysis.

\section{Results}

There was no significant difference between the $\mathrm{KP}$ and MLF groups in terms of age, gender, body-mass index (BMI), smoking habits, history of acute abscess drainage (HAAD), timing of suture removal (TSR), follow-up period (FP), seroma, hematoma, dehiscence, WI, pain and recurrence (Table 1). Continuous variables were found to be homogeneously distributed by using the Kolmogorov-Smirnov test, $(p>0.05)$. The ASA scores, timing of drain removal (TDR), hospitalization period (HP) and return to daily activity (RDA) were found to be higher in the KP group than those in the MLF group (Table 1). The number of $\mathrm{PD}$ patients underwent spinal anesthesia in the MLF group was higher than that of the KP group. In the MLF group, the duration of surgical operation (DO) was found to be higher than that of the KP group (Table 1).

In this study, the follow-up period of patients was $48.6 \pm 21.4$ months in KP group and $48.2 \pm$

Table 1. General characteristics according to patients groups

\begin{tabular}{|c|c|c|c|c|c|c|}
\hline & & \multicolumn{2}{|c|}{$\begin{array}{l}\text { KP Group } \\
(\mathrm{n}=417)\end{array}$} & \multicolumn{2}{|c|}{$\begin{array}{l}\text { MLF Group } \\
(\mathrm{n}=424)\end{array}$} & $p$ \\
\hline Age (Years) & & \multicolumn{2}{|c|}{$25.8 \pm 8.1$} & \multicolumn{2}{|c|}{$25.7 \pm 7.3$} & 0.994 \\
\hline $\mathrm{BMI}\left(\mathrm{kg} / \mathrm{m}^{2}\right)$ & & \multicolumn{2}{|c|}{$26.7 \pm 4.0$} & \multicolumn{2}{|c|}{$26.4 \pm 3.1$} & 0.218 \\
\hline Gender+ & $\begin{array}{l}\text { Female (\%) } \\
\text { Male (\%) }\end{array}$ & $\begin{array}{c}91 \\
326\end{array}$ & $\begin{array}{l}21.8 \% \\
78.1 \%\end{array}$ & $\begin{array}{l}115 \\
309\end{array}$ & $\begin{array}{l}27.1 \% \\
72.8 \%\end{array}$ & 0.062 \\
\hline $\mathrm{ASA}+$ & $\begin{array}{l}1(\%) \\
2(\%)\end{array}$ & $\begin{array}{c}330 \\
87\end{array}$ & $\begin{array}{l}79.1 \% \\
20,9 \%\end{array}$ & $\begin{array}{c}415 \\
9\end{array}$ & $\begin{array}{l}97.9 \% \\
2.1 \%\end{array}$ & $0.001^{*}$ \\
\hline Smoking + & $\begin{array}{l}\text { Not Smoking (\%) } \\
\text { Smoker (\%) }\end{array}$ & $\begin{array}{l}170 \\
247\end{array}$ & $\begin{array}{l}40.7 \% \\
59.2 \%\end{array}$ & $\begin{array}{l}165 \\
259\end{array}$ & $\begin{array}{l}38.9 \% \\
61.0 \%\end{array}$ & 0.583 \\
\hline Anesthesia Type + & $\begin{array}{l}\text { General (\%) } \\
\text { Spinal (\%) }\end{array}$ & $\begin{array}{l}127 \\
290\end{array}$ & $\begin{array}{l}30.46 \% \\
69.54 \%\end{array}$ & $\begin{array}{c}53 \\
371\end{array}$ & $\begin{array}{l}12.50 \% \\
87.50 \%\end{array}$ & $0.001^{*}$ \\
\hline HAAD+ & $\begin{array}{l}\text { None (\%) } \\
\text { Yes (\%) }\end{array}$ & $\begin{array}{l}149 \\
268\end{array}$ & $\begin{array}{l}35.7 \% \\
64.3 \%\end{array}$ & $\begin{array}{l}135 \\
289\end{array}$ & $\begin{array}{l}31.8 \% \\
68.2 \%\end{array}$ & 0.233 \\
\hline DO (Minutes) & & \multicolumn{2}{|c|}{$28.4 \pm 4.8$} & \multicolumn{2}{|c|}{$36.7 \pm 4.2$} & $0.001^{*}$ \\
\hline HP (Days) & & \multicolumn{2}{|c|}{$2.3 \pm 1.6$} & \multicolumn{2}{|c|}{$1.4 \pm 0.7$} & 0.001 * \\
\hline TDR (Days) & & \multicolumn{2}{|c|}{$4.9 \pm 0.8$} & \multicolumn{2}{|c|}{$1.4 \pm 0.7$} & $0.001^{*}$ \\
\hline TSR (Days) & & \multicolumn{2}{|c|}{$10.8 \pm 0.8$} & \multicolumn{2}{|c|}{$10.8 \pm 0.9$} & 0.149 \\
\hline RDA (Days) & & \multicolumn{2}{|c|}{$5.4 \pm 1.4$} & \multicolumn{2}{|c|}{$4.0 \pm 1.0$} & $0.001 *$ \\
\hline FT (Months) & & \multicolumn{2}{|c|}{$48.6 \pm 21.4$} & \multicolumn{2}{|c|}{$48.2 \pm 21.7$} & 0.814 \\
\hline Early Complications+ & $\begin{array}{l}\text { Hematoma } \\
\text { Seroma } \\
\text { Dehiscence } \\
\text { Infection } \\
\text { Pain }\end{array}$ & $\begin{array}{c}10 \\
6 \\
34 \\
11 \\
2\end{array}$ & $\begin{array}{l}2.40 \% \\
1.44 \% \\
8.15 \% \\
2.64 \% \\
0.48 \%\end{array}$ & $\begin{array}{c}12 \\
10 \\
24 \\
23 \\
2\end{array}$ & $\begin{array}{l}2.83 \% \\
2.36 \% \\
5.66 \% \\
5.42 \% \\
0.47 \%\end{array}$ & $\begin{array}{l}0.834 \\
0.458 \\
0.265 \\
0.065 \\
0.997\end{array}$ \\
\hline Late Complications+ & $\begin{array}{l}\text { Chronic Back Pain } \\
\text { Recurrence }\end{array}$ & $\begin{array}{c}2 \\
25\end{array}$ & $\begin{array}{l}0.48 \% \\
6.00 \%\end{array}$ & $\begin{array}{c}2 \\
20\end{array}$ & $\begin{array}{l}0.47 \% \\
4.72 \%\end{array}$ & $\begin{array}{l}0.995 \\
0.338\end{array}$ \\
\hline
\end{tabular}

KP: Karydakis procedure, MLF: Modified Limberg flap. BMI: Body mass index, ASA: American Society of Anesthesiologists physical status classification scores, HAAD: History of acute abscess drainage, DO: Duration of operation, HP: Hospitalization period, TDR: Timing of drain removal, TSR: Timing of suture removal, RDA: Return to daily activity, and FT: Follow-up time.+Chi-square test was used for statistical analysis. In others, independent $t$ test was used for statistical analysis. Continuous data are presented as means \pm SD (Standard Deviation), and categorical data are presented as number (percentage). ${ }^{*} \mathrm{p}<0.05$ 
21.7 months in MLF group (Table 1).

We did not find a relationship between age, gender, smoking, HP, TDR, or TSR and the appearance of early complications (EC) development in both groups (Table 2).

We determined that high ASA scores had an enhancing effect on the EC development in the KP group. However, this relationship was not established in the MLF group (Table 2).

There was an established enhancing effect of BMI, HAAD, DO, and RDA on the EC development in both groups (Table 2).

Recurrence was observed in 25 patients $(6 \%)$ in the KP group and in 20 patients $(4.72 \%)$ in the MLF group (Table 1). The patients who developed recurrence were treated by KP, open healing $(\mathrm{OH})$ or marsupialization techniques as re-operation techniques. The relationship between EC and recurrence in both groups was evaluated (Table 3). The dehiscence and WI were found to be independent risk factors for recurrence in both groups $(p<0.001)$. Neither hematoma nor seroma was found to be a risk factor for recurrence in both groups.

\section{Discussion}

PD was considered a deficiency in the dorsal midline fusion in the past. It is now accepted as an acquired disease $(1,7,14,19)$. However there is no consensus on the treatment of chronic PD $(6,12)$. Following the excision towards the sacral fascia, open healing $(\mathrm{OH})$ and primary closure $(\mathrm{PC})$ are still

Table 2. Evaluation of the relationship between general characteristics and early complications according to patients groups

\begin{tabular}{|c|c|c|c|c|c|c|c|}
\hline \multirow{3}{*}{\multicolumn{2}{|c|}{ General Characteristics }} & \multicolumn{6}{|c|}{ Early complications } \\
\hline & & \multicolumn{3}{|c|}{ KP Group $(n=417)$} & \multicolumn{3}{|c|}{ MLF Group $(n=424)$} \\
\hline & & $\begin{array}{c}\text { None } \\
(n=354)\end{array}$ & $\begin{array}{c}\text { Yes } \\
(n=63)\end{array}$ & p & $\begin{array}{c}\text { None } \\
(n=353)\end{array}$ & $\begin{array}{c}\text { Yes } \\
(n=71)\end{array}$ & p \\
\hline \multicolumn{2}{|l|}{ Age (Years) } & $25.6 \pm 7.8$ & $26.8 \pm 9.5$ & 0.251 & $25.7 \pm 7.2$ & $26.2 \pm 7.8$ & 0.555 \\
\hline \multicolumn{2}{|l|}{$\mathrm{BMI}\left(\mathrm{kg} / \mathrm{m}^{2}\right)$} & $26.4 \pm 3.8$ & $28.1 \pm 4.9$ & $0.002^{*}$ & $25.9 \pm 2.9$ & $28.8 \pm 3.1$ & $0.001^{*}$ \\
\hline Gender+ & $\begin{array}{l}\text { Female } \\
(\%) \\
\text { Male } \\
(\%)\end{array}$ & $\begin{array}{c}82 \\
(23.1) \\
272 \\
(76.9)\end{array}$ & $\begin{array}{c}9 \\
(14.2) \\
54 \\
(85.8)\end{array}$ & 0.116 & $\begin{array}{c}94 \\
(26.6) \\
259 \\
(73.4)\end{array}$ & $\begin{array}{c}21 \\
(29.6) \\
50 \\
(70.4)\end{array}$ & 0.610 \\
\hline $\mathrm{ASA}+$ & $\begin{array}{l}1 \\
(\%) \\
2 \\
(\%)\end{array}$ & $\begin{array}{c}291 \\
(83.2) \\
63 \\
(17.8)\end{array}$ & $\begin{array}{c}39 \\
(61.9) \\
24 \\
(38.1)\end{array}$ & $0.001^{*}$ & $\begin{array}{c}346 \\
(98) \\
7 \\
(2)\end{array}$ & $\begin{array}{c}69 \\
(97.2) \\
2 \\
(2.8)\end{array}$ & 0.656 \\
\hline Smoking+ & $\begin{array}{l}\text { No Smoking } \\
(\%) \\
\text { Smoker } \\
(\%)\end{array}$ & $\begin{array}{c}149 \\
(41.1) \\
205 \\
(57.9)\end{array}$ & $\begin{array}{c}21 \\
(33.3) \\
42 \\
(66.7)\end{array}$ & 0.192 & $\begin{array}{c}133 \\
(37.7) \\
220 \\
(62.3)\end{array}$ & $\begin{array}{c}32 \\
(45.1) \\
39 \\
(54.9)\end{array}$ & 0.244 \\
\hline $\mathrm{HAAD+}$ & $\begin{array}{l}\text { None } \\
(\%) \\
\text { Yes } \\
(\%)\end{array}$ & $\begin{array}{c}134 \\
(37.9) \\
220 \\
(67.1)\end{array}$ & $\begin{array}{c}15 \\
(23.8) \\
48 \\
(76.2)\end{array}$ & $0.032^{*}$ & $\begin{array}{c}102 \\
(28.9) \\
251 \\
(71.2)\end{array}$ & $\begin{array}{c}33 \\
(46.5) \\
38 \\
(53.5)\end{array}$ & $0.004^{*}$ \\
\hline \multicolumn{2}{|c|}{ D0 (Minutes) } & $28.1 \pm 4.6$ & $30.3 \pm 5.4$ & $0.001^{*}$ & $36.3 \pm 4.2$ & $38.4 \pm 4.2$ & $0.001^{*}$ \\
\hline \multicolumn{2}{|l|}{ HP (Days) } & $2.3 \pm 1.0$ & $2.7 \pm 3.2$ & 0.064 & $1.4 \pm 0.7$ & $1.2 \pm 0.6$ & 0.106 \\
\hline \multicolumn{2}{|l|}{ TDR (Days) } & $4.9 \pm 0.9$ & $5.1 \pm 1.0$ & 0.168 & $1.4 \pm 0.7$ & $1.2 \pm 0.6$ & 0.090 \\
\hline \multicolumn{2}{|l|}{ TSR (Days) } & $10.9 \pm 0.9$ & $11.0 \pm 1.0$ & 0.519 & $10.6 \pm 0.8$ & $10.8 \pm 0.9$ & 0.115 \\
\hline \multicolumn{2}{|l|}{ RDA (Days) } & $5.3 \pm 0.9$ & $5.9 \pm 3.0$ & $0.002^{*}$ & $3.9 \pm 0.9$ & $4.5 \pm 1.0$ & $0.001^{*}$ \\
\hline
\end{tabular}

KP: Karydakis procedure, MLF: Modified Limberg flap, BMl: Body-mass index, ASA: American Society of Anesthesiologists physical status classification scores, HAAD: History of acute abscess drainage, DO: Duration of operation, HP: Hospitalization period TDR: Timing of drain removal, TSR: Timing of suture removal, RDA: Return to daily activity.+Chi-square test was used for statistical analysis. In others, independent $t$ test was used for statistical analysis. Continuous data are presented as means \pm SD (Standard Deviation), and categorical data are presented as number (percentage). ${ }^{\star} p<0.05$. 
Table 3. Evaluation of the relationship between early complications and recurrenceaccording to patients groups

\begin{tabular}{|c|c|c|c|c|c|c|}
\hline \multirow[b]{2}{*}{ Early complication } & \multicolumn{3}{|c|}{$\begin{array}{l}\text { Recurrence in KP Group } \\
(\mathrm{n}=417)\end{array}$} & \multicolumn{3}{|c|}{$\begin{array}{l}\text { Recurrence in MLF Group } \\
(\mathrm{n}=424)\end{array}$} \\
\hline & $\begin{array}{l}\text { None } \\
(\mathrm{n}: 392)\end{array}$ & $\begin{array}{l}\text { Yes } \\
(n: 25)\end{array}$ & $\mathrm{p}$ & $\begin{array}{c}\text { None } \\
(\mathrm{n}: 404)\end{array}$ & $\begin{array}{l}\text { Yes } \\
(\mathrm{n}: 20)\end{array}$ & $\mathrm{p}$ \\
\hline $\begin{array}{l}\text { None } \\
(\%)\end{array}$ & $\begin{array}{c}356 \\
(90.3)\end{array}$ & 0 & $0.001^{*}$ & 355 & 0 & $0.001^{*}$ \\
\hline $\begin{array}{l}\text { Hematoma } \\
(\%)\end{array}$ & $\begin{array}{c}10 \\
(2.6)\end{array}$ & 0 & 0.419 & $\begin{array}{c}11 \\
(2.7)\end{array}$ & $\begin{array}{l}1 \\
(5)\end{array}$ & 0.549 \\
\hline $\begin{array}{l}\text { Seroma } \\
(\%)\end{array}$ & $\begin{array}{c}6 \\
(1.5)\end{array}$ & 0 & 0.533 & $\begin{array}{c}9 \\
(2.2)\end{array}$ & $\begin{array}{c}1 \\
(5)\end{array}$ & 0.425 \\
\hline $\begin{array}{l}\text { Dehiscence } \\
(\%)\end{array}$ & $\begin{array}{c}14 \\
(3.6)\end{array}$ & $\begin{array}{l}20 \\
(80)\end{array}$ & $0.001^{*}$ & $\begin{array}{c}13 \\
(3,2)\end{array}$ & $\begin{array}{l}11 \\
(55)\end{array}$ & $0.001^{*}$ \\
\hline $\begin{array}{l}\text { WI } \\
(\%)\end{array}$ & $\begin{array}{c}6 \\
(1.5)\end{array}$ & $\begin{array}{c}5 \\
(20)\end{array}$ & $0.001^{*}$ & $\begin{array}{c}16 \\
(3,9)\end{array}$ & $\begin{array}{c}7 \\
(35)\end{array}$ & $0.001^{\star}$ \\
\hline
\end{tabular}

the most commonly used surgical techniques. $\mathrm{PC}$ can be done in the form of asymmetric (OMPCT) or midline closure $(4,20)$. In their meta-analysis, McCallum et al. reported that the PC provided rapid recovery despite the high risk of recurrence compared to $\mathrm{OH}$, and emphasized the importance of using OMPCT as a standard treatment if $\mathrm{PC}$ is preferred in the same study. These investigators determined the rates of recurrence were $1.4 \%$ in the OMPCT and $10.3 \%$ in the midline PC techniques (4).

Karydakis procedure (KP) and Limberg Flap (LF) techniques are frequently applied in the OMPCT. Following the introduction of geometric analysis in paper models in 1946, LF technique was accepted a wide range of application and defined as a new method for PD in $1984(5,21,22)$. Various modifications of this technique were also developed to prevent recurrences after LF applications (5). The KP technique, previously defined as the new approach for PD in 1973, has also undergone various modifications to date $(17,18)$. In the current study, we aimed to evaluate the descriptive features of the patients with PD, the appearance of early complications and late complications (LC) obtained from the patients treated with either KP (17) or MLF (5) techniques, and the effects of some factors such as smoking, BMI, the history of acute abscess drainage (HAAD) on morbidity.

A 501 PD patient study by Sievert et al showed that smoking and body weight as lifestyle parameters did not significantly affect wound healing or recurrence rates during the first 20 years following primary PD surgery (23). However, these investigators emphasized the necessity of investigating the effects of BMI (25 and higher)on wound healing in flap surgery. In our study, we found that BMI was high in the patients with EC in both groups (Table 2). In view of this finding, it can be stated that high BMI is a risk factor for the EC development in both groups.

Søndenaa et al stated that $54 \%$ of patients had a history of acute infection (3). In our study, 64.3\%patients in the KP group and $68.2 \%$ patients in the MLF group had a HAAD (Table 1). There was no difference between the groups. Presence of HAAD enhanced the EC development in both KP and MLF groups $(\mathrm{P}=0.032, \mathrm{P}=0.004$, respectively), (Table 2). Due to the frequent occurrence of HAAD cases, the number of pinholes settling outside the midline or midline can increase, thus rendering the disease more complicated. Furthermore the presence of multiple pinholes may lead to high EC rates in patients with HAAD. 
In a prospective randomized study by Tokac et al (7), the mean duration time of operation (DO) was found to be $44.5 \pm 6.6 \mathrm{~min}$ in MLF and $42.9 \pm 6.2 \mathrm{~min}$ in KP. We observed that the DO in both groups was shorter than that of the Tokac group (Table 1). When DO was compared for both groups, the mean DO was found higher in the MLF group (Table 1) due to the technical details of this method. In both groups, we observed that DO was significantly longer in the patients with EC (Table 2).

In the Karaca et al study, the mean hospitalization period (HP) was $1 \pm 0.1$ days in MLF and 1 day in KP groups (12). Can et al (8), compared KP and MLF techniques and found the HP of both groups $5.5 \pm 2$ days and $4.8 \pm 2.6$ days, respectively. Mentes et al. reported the patients who received the MLF procedure had $8.0 \pm 2.5$ day return to daily activity and a 2.1 day mean HP (5). The mean HP in the LF technique was observed $3.61 \pm 1.08$ days by Ersoy et al (15) and one day by Altinparmak et al (19). Yildiz et al, determined the mean length of HP in KP $3.34 \pm 1.42$ days (13). In our study, $\mathrm{HP}$ and RDA were consistent with the values reported in literature in the both groups. Moreover, our KP group had a longer duration of $\mathrm{HP}$ and RDA compared to our MLF group (Table 1). Furthermore, we found that RDA was higher in the patients with EC in both groups (Table 2). We think that this situation may be associated with high ASA values in KP group (Tables 1, 2).

In the work of Sewefy et al (14), patients were divided into two groups after standard KP applied in the PD treatment. These investigators applied a drain to a group and sutures tie-over compressing the other group without a drain. In their study, the factors such as HP, return to work, seroma, and wound infection (WI)were found to be $4.9 \pm 2.4$ days, $12.6 \pm 4$ days, $7.8 \%, 9.1 \%$, respectively. When compared to the Sewefy et al study, the rate of seroma and WI cases was lower in our study and the HP was found to be shorter (Tables 1, 2). In this study, the TDR was not reported (14). We found the average TDR was $4.97 \pm 0.86$ days in the KP group. In addition, we could not correlate the EC development with TDR in both groups (Table 2). Cetin et al showed the average TDR was $4.4 \pm 1.5$ days in patients of LF group with mattress sutures (24).

Total complication rate in patients undergoing OMPCT are varied in the literature. Bessa (17) reported a $7.3 \%$ the complication rate in $\mathrm{KP}$ while Onder et al (6) determined the complication rate $34 \%$ in LF.

Study by Karydakis (18) indicated the rate of hematoma $8.5 \%$, the rate of WI $8.5 \%$ and the average HP 8.2 days in 1687 patients who underwent KP. The rate of hematoma and WI in our KP group was determined 2.4\%, 2.6\%, respectively. The rates of hematoma after $\mathrm{LF}$ were reported differently to be $6.8 \%, 24 \%$, $3.3 \%$ in studies by Ersoy et al (15), by Akan et al (25), and by Altintoprak et al (19), respectively. The rate of hematoma in our MLF group was found to be lower than in aforementioned studies (Tables 1 and 4). In addition, we did not determine hematoma as a risk factor for recurrence in both groups (Table 3).

Bessa reported a seroma rate $2.4 \%$ in their KP study (17). Seroma rates after LF were reported to be $6 \%$ by Akan et al (25) and $7.7 \%$ by Altintoprak et al (19). The rates in our study were lower for both groups compared to the previous studies (Tables 1 and 4). Furthermore, we did not determine seroma as a risk factor for recurrence in both groups (Table 3).

The rates of dehiscence between $4.4 \%$ and $11.4 \%$ have been reported for KP in Table 4 $(8,12)$. In our KP group, the dehiscence rate was $8.1 \%$, which was consistent with the values reported in literature. The rates of dehiscence in LF were reportedto be $4.5 \%$ by Ersoy et al (15), $8 \%$ by Akan et al (25) and $5.5 \%$ by Altintoprak et al (19). In our MLF group, the dehiscence rate was $5.66 \%$, which was consistent with the values reported in literature. In current study, we found that dehiscence was an independent risk factor for recurrence-risk ratio in both group of patients (Table 3).

Using meta-analysis, McCallum et al reported $6.3 \%$ wound infection (WI) in the OMPCT (4). Tokac et al, additionally, reported $6.6 \% \mathrm{WI}$ in MLF and this value was very similar in KP, $6.5 \%$ (7). Using MLF technique, 
Table 4. Evaluation of complication rates (\%) in literature with Karydakis and Limberg Flap techniques *The rates of hematoma in Can (8) and Bessa (26) studies are unclear

\begin{tabular}{|c|c|c|c|c|c|c|c|}
\hline & & Can (8) & Karaca (12) & Bessa (26) & Bali (27) & Ates (28) & Demiryas \\
\hline \multirow[t]{6}{*}{ Karydakis Group } & Total complications (\%) & 15.7 & 39.9 & 20 & 49.9 & 14.0 & 15.1 \\
\hline & Seroma (\%) & 1.5 & 17.1 & 5 & 11.7 & 1.4 & 1.4 \\
\hline & Hematoma (\%) & * & 0 & * & 8.8 & 0.7 & 2.4 \\
\hline & Infection (\%) & 4.4 & 5.7 & 3.33 & 23.5 & 2.9 & 2.6 \\
\hline & Dehiscence (\%) & 4.4 & 11.4 & 10 & 5.8 & 5.9 & 8.1 \\
\hline & Recurrence (\%) & 5.4 & 5.7 & 1.67 & 0 & 2.9 & 6 \\
\hline \multirow[t]{6}{*}{ Limberg Group } & Total complications (\%) & 17.8 & 4.2 & 26.6 & 43.2 & 27.6 & 16.7 \\
\hline & Seroma $(\%)$ & 3.9 & 4.2 & 0 & 8.1 & 2.2 & 2.3 \\
\hline & Hematoma (\%) & * & 0 & * & 21.6 & 2.2 & 2.8 \\
\hline & Infection (\%) & 5.2 & 0 & 5 & 10.8 & 5.9 & 5.4 \\
\hline & Dehiscence (\%) & 3.9 & 0 & 18.3 & 2.7 & 10.4 & 5.6 \\
\hline & Recurrence (\%) & 4.8 & 0 & 3.3 & 0 & 6.7 & 4.7 \\
\hline
\end{tabular}

$0.8 \%$ WI rate was observed by Mentes et al (5). The other investigators reported different WI rates; $4.5 \%$ by Ersoy et al (15), 34\% by Akan et al (25), $5 \%$ by Dass et al (16), 6.6\% by Altintoprak et al (19), and $13 \%$ by Cetin et al (24). WI rate was $5.4 \%$ in our MLF group. Bessa (17), on the other hand, reported a WI rate of $4.9 \%$ of patients who underwent KP procedure. WI rate was $2.64 \%$ in our KP group. In our study, we concluded that WI as early complications was an independent risk factor for recurrence in both groups (Table 3).

Bessa et al reported no recurrence (0\%) after $\mathrm{KP}$ in a series of 80 cases (17). While a report by Onder (6) showed this rate at 5.7\%, Yildiz et al (13) observed a 2.3\% recurrence rate in KP. Mentes et al also found recurrence $0 \%$ in MLF and $1.26 \%$ in classic LF (5). In Tokac et al study, recurrence rates were reported to be $6.5 \%$ in MLF and $4.4 \%$ in KP (7). In our study, the recurrence rates in both groups were consistent with the values reported in literature. We did not observe any difference between these groups in terms of recurrence rates (Tables 1, 4).

In the literature, we found no study evaluating the relationship between EC and recurrence. In this current study, recurrence was only seen among patients who developed EC. Furthermore, we found that dehiscence or WI was an independent risk factor for recurrence, in both groups. Clearly, we also reduced the risk of recurrence by applying the necessary treatments (such as wet dressing, antibiotherapy) in patients with dehiscence or WI. Moreover, we found that hematoma or seroma was not a risk factor for recurrence. This result may be associated with taking necessary medical precautions.

In the current literature, the variations in the complication rates are unexpectedly high or low when evaluating complications in clinical studies comparing KP and LF modifications in PD $(8,12,26-28)$. It seems to be due to the small number of patients with $\mathrm{PD}$ in previous studies. Notwithstanding retrospective analysis, this study has significant advantages: a large number of PD patients, a long follow-up period, and surgeons' performing uniform surgical technique. However, we should have evaluated adequately patients in terms of acute postoperative pain or scar satisfaction. In addition, our study obviously has some limitations and methodological setbacks, due to its retrospective nature and design. However, there is a need for more randomized controlled clinical trials.

\section{Conclusion}

In conclusion, although its duration of operation is short, KP technique bears some of the disadvantages such as prolonged hospitalization period and delayed return to 
routine daily activity. A significant positive correlation was found between various factors such as higher BMI, presence of HAAD (History of acute abscess drainage), prolonged DO, prolonged RDA and the development of early complication in both groups. We reached the conclusion that dehiscence and wound infection from EC may be evaluated independent risk factors for recurrence. We also concluded that recurrence may be prevented if wound care is carried out carefully in the patients developed dehiscence or WI. The choice of an appropriate surgical technique for PD should be associated with patient compliance and the experience of the surgeon.

\section{Conflicts of Interest}

Authors declare no competing commercial, personal, political, intellectual or religious conflicts of interest in relation to our study. No grant or other financial support has been received for this work.

\section{Acknowledgments}

We would like to thank Dr. Ziya Cerkezi (Department of General Surgery, Esenyurt Necmi Kadioglu Government Hospital, Istanbul, Turkey) for his contributions in the material collection activities and Rana Konyalıoğlu (Biostatistician) for statistical analysis.

\section{References}

1. Khanna A, Rombeau J. Pilonidal Disease. Clin Colon Rectal Surg. 2011;24(01):046-53.

2. Bascom J. Surgical treatment of pilonidal disease. BMJ. 2008;336:842-3.

3. Søndenaa K, Andersen E, Nesvik I, Søreide JA. Patient characteristics and symptoms in chronic pilonidal sinus disease. Int $\mathrm{J}$ Colorectal Dis. 1995;10(1):39-42.

4. McCallum IJD, King PM, Bruce J. Healing by primary closure versus open healing after surgery for pilonidal sinus: systematic review and meta-analysis. BMJ. 2008;336:868-71.

5. Mentes BB, Leventoglu S, Cihan A, Tatlicioglu E, Akin M, Oguz M. Modified Limberg Transposition Flap for Sacrococcygeal Pilonidal Sinus. Surg Today. 2004;34(5):419-23.

6. Onder A, Girgin S, Kapan M, Toker M, Arikanoglu Z, Palanci Y, et al. Pilonidal Sinus Disease: Risk Factors for Postoperative
Complications and Recurrence. Int Surg. 2012;97(3):224-9.

7. Tokac M, Dumlu EG, Aydin MS, Yalcın A, Kilic M. Comparison of Modified Limberg Flap and Karydakis Flap Operations in Pilonidal Sinus Surgery: Prospective Randomized Study. Int Surg. 2015;100(5):870-7.

8. Can MF, Sevinc MM, Hancerliogullari 0, Yilmaz M, Yagci G. Multicenter prospective randomized trial comparing modified Limberg flap transposition and Karydakis flap reconstruction in patients with sacrococcygeal pilonidal disease. Am J Surg. 2010; 200(3):318-27.

9. Dessily M, Charara F, Ralea S, Allé J-L. Pilonidal sinus destruction with a radial laser probe: technique and first Belgian experience. Acta Chir Belg. 2017;117(3):164-8.

10. Lund J, Tou S, Doleman B, Williams JP. Fibrin glue for pilonidal sinus disease. Cochrane Database Syst Rev [Internet]. 2017;1:CD011923.

11. Wysocki AP. Pilonidal Sinus Disease: Are Naval Mines Relevant? World J Surg. 2017;41(11):2968-9.

12. Karaca $T$, Yoldaş Ö, Bilgin BÇ, Özer S, Yoldaş S, Karaca NG. Comparison of short-term results of modified Karydakis flap and modified Limberg flap for pilonidal sinus surgery. Int $J$ Surg. 2012;10(10):601-6.

13. Yildiz MK, Ozkan E, Odabaşı HM, Kaya B, Eriş C, Abuoğlu HH, et al. Karydakis Flap Procedure in Patients with Sacrococcygeal Pilonidal Sinus Disease: Experience of a Single Centre in Istanbul. Sci World J. 2013;2013:1-4.

14. Sewefy AM, Hassanen A, Atyia AM, Saleh SK. Karydakis Flap With Compressing Tie-over Interrupted Sutures Without Drain versus Standard Karydakis for Treatment of Sacrococcygeal Pilonidal Sinus Disease. Dis Colon Rectum. 2017;60(5):514-20.

15. Ersoy OF, Kayaoglu HA, Ozkan N, Celik A, Karaca S, Ozum T. Comparison of Different Surgical Options in the Treatment of Pilonidal Disease: Retrospective Analysis of 175 Patients. Kaohsiung J Med Sci. 2007;23(2):67-70.

16. Dass TA, Zaz M, Rather A, Bari S. Elliptical Excision with Midline Primary Closure Versus Rhomboid Excision with Limberg Flap Reconstruction in Sacrococcygeal Pilonidal Disease: A Prospective, Randomized Study. Indian J Surg. 2012;74(4):305-8.

17. Bessa SS. Results of the Lateral Advancing Flap Operation (Modified Karydakis Procedure) for the Management of Pilonidal Sinus Disease. Dis Colon Rectum. 2007;50(11):1935-40.

18. Karydakis GE. New approach to the problem of pilonidal sinus. Lancet. 1973;2(7843):1414-5.

19. Fatih $A$, Enis $D$, Yusuf A, Taner 0 , Gokhan A, Nuri DO. Comparision of the Limberg flap with the $\mathrm{V}-\mathrm{Y}$ flap technique in the treatment of pilonidal disease. J Korean Surg Soc. 2013;85(2):63.

20. Di Castro A, Guerra F, Levi Sandri GB, Ettorre GM. Minimally invasive surgery for the treatment of pilonidal disease. The Gips procedure on 2347 patients. Int J Surg. 2016;36:201-5.

21. Green AR. Use of the rhomboid flap in pilonidal sinus. Ann R Coll Surg Engl. 1986;68(5):293-4.

22. Azab AS, Kamal MS, Saad RA, Abou al Atta KA, Ali NA. Radical cure of pilonidal sinus by a transposition rhomboid flap. $\mathrm{Br} \mathrm{J}$ Surg. 1984;71(2):154-5.

23. Sievert H, Evers T, Matevossian E, Hoenemann C, Hoffmann S, Doll $D$. The influence of lifestyle (smoking and body mass index) on wound healing and long-term recurrence rate in 534 primary pilonidal sinus patients. Int J Colorectal Dis. 2013;28(11):1555-62. 24. Çetin K, Sikar HE, Kocaoğlu AE, Kündeş MF, Karahan M, Kaptanoğlu 
L. Evaluation of intradermal absorbable and mattress sutures to close pilonidal sinus wounds with Limberg flap: a prospective randomized comparative study. Ann Surg Treat Res. 2018;94(2):88.

25. Akan K, Tihan D, Duman U, Ozgun Y, Erol F, Polat M. Comparison of surgical Limberg flap technique and crystallized phenol application in the treatment of pilonidal sinus disease: a retrospective study. Turkish J Surg. 2014;29(4):162-6.

26. Bessa SS. Comparison of Short-term Results Between the Modified Karydakis Flap and the Modified Limberg Flap in the Management of Pilonidal Sinus Disease. Dis Colon Rectum. 2013;56(4):491-8.

27. Bali I, Aziret M, Sözen S, Emir S, Erdem H, Çetinkünar S, et al. Effectiveness of Limberg and Karydakis flap in recurrent pilonidal sinus disease. Clinics. 2015;70(5):350-5.

28. Ates M, Dirican A, Sarac M, Aslan A, Colak C. Short and long-term results of the Karydakis flap versus the Limberg flap for treating pilonidal sinus disease: a prospective randomized study. Am J Surg. 2011;202(5):568-73. 